\title{
Guest Editorial: New Frontiers in Accessibility Modelling: An Introduction
}

\author{
Aura Reggiani • Juan Carlos Martín
}

Published online: 19 February 2011

(C) Springer Science+Business Media, LLC 2011

There is a well established body of research that deals with how accessibility affects land use planning and spatial interaction. Hansen (1959) is usually cited as the father of this "scientific term". In his seminal work, he defines accessibility as "the potential of opportunities for interaction" (p.73). Since then, the interest of how transport systems and spatial interaction are related has grown exponentially and accessibility analysis has played for more than five decades a central role in the agenda of regional and transport research.

The concept of accessibility is open to different areas of study regarding the activities that can be carried out, to multiple transport systems and to different individuals or groups, so it is not surprising that in the literature we can find many different definitions (Geurs and van Wee 2004; Bruinsma and Rietveld 1998; Reggiani 1998; Vickerman 1995; and Morris et al. 1979). Handy and Niemeier (1997) showed that different types of accessibility measures exist according to particular criteria, and it is difficult to suggest the best approach to measure accessibility because different situations and purposes demand different approaches. This comment is quite pertinent at the light of the articles included in our special issue. We will see that four of them analyze accessibility in commuting and the authors use different methods, demarcation areas and opportunities are in some cases aggregated at the level of areas or individuals.

In the last decade with the continuing development and deployment of geographic information systems (GIS) and other geospatial technologies that have greatly enhanced the ability to collect and analyse data relevant to accessibility analysis, researchers, in some cases, have changed from place-based measures of accessibility

\footnotetext{
A. Reggiani $(\bowtie)$

Department of Economics, Faculty of Statistics, University of Bologna, Piazza Scaravilli, 2, 40126

Bologna, Italy

e-mail: aura.reggiani@unibo.it

J. C. Martín ( $\square)$

Department of Applied Economic Analysis, University of Las Palmas de Gran Canaria,

Campus de Tafira, 35017 Las Palmas de Gran Canaria, Spain

e-mail: jcmartin@daea.ulpgc.es
} 
to people-based measures that are more sensitive to individual activity patterns and accessibility in space and time (Miller 2005; Kwan 1998). Weber and Kwan (2003) sustain that place-based accessibility indicators are often incomplete, because individual and household characteristics can have a much stronger influence on accessibility than place. In the same line, Kwan (1998) shows how different people in the same home or workplace can have strikingly different activity, travel, and interaction patterns. This apparent paradox about heterogeneity is also analyzed in some articles of this Special Issue.

As previously outlined, accessibility in its seminal definition by Hansen and subsequent studies was formerly analysed as the potential of opportunity for interaction. In particular, accessibility refers to the 'properties of the configuration of opportunities for spatial interaction' (Weibull 1980, p. 54). Accessibility then measures the propensity of economic actors/users to reach certain economic activities/destinations. Thus, different types of infrastructure and socio-economic networks might give rise to different accessibility patterns. The main question is whether the accessibility models conventionally used in spatial-economic science are able, first, to grasp the homogeneity/heterogeneity of the spatial system concerned, and, second, to investigate the associated connectivity infrastructure/economic network.

The accessibility concept has then evolved by becoming enriched with economic and social content that include relevant aspects of industrial organization, network economics and land use. Taking this evolution into account, different indicators have been proposed in the literature, but all of them present some fundamental elements that can be characterized as follows:

- The area of study in which the transport network plays an important functional role by facilitating the spatial interaction between the zones;

- The transport network (also non physical, e.g. the communication network) that is considered for the specific purpose of the study. Without transport networks spatial interaction between zones would be negligible;

- Different economic activities that may be carried on in the area of study;

- The people or group of individuals/economic actors who usually benefit for participating in different economic activities. Thus, they need to use the transport system to travel between two or more nodes included in the area of study.

Reflections on the relationships between the different areas of study, transport networks, economic activities and the individuals or groups under analysis, certainly remain a valid tool that characterize the articles included in this Special Issue. This number intends, first, to provide, new analytical insights into the modelling and analysis of accessibility, balancing place-based measures of accessibility vs. peoplebased measures; and, second, to constitute a point of reference that can be used by other researchers in future applications.

The idea of this Special Issue originates from the first NECTAR ${ }^{1}$ (Network for European Communication and Transport Activities Research) Workshop on Accessibility, organized in Las Palmas de Gran Canaria, Spain, in June 2008.

\footnotetext{
${ }^{1}$ http://www.nectar-eu.org/
} 
Within this framework, the editors wish to thank the University of Las Palmas de Gran Canaria and its staff for their great scientific input and organizational support.

From the Conference papers and other personal invitations we have gathered six particular contributions that aim-as mentioned-to develop new accessibility models and to analyse the results on the basis of different elements included in the models. Table 1 can be used to link the six articles included in the Special Issue.

From Table 1, it is clear that the research topics developed in the six articles mainly deal with accessibility in commuting, however the models are very different and shed new light that can be used for future research. The papers can also be grouped into two fundamental methodological characteristics:

a) The place-accessibility measures (papers by Östh; Reggiani et al.; and El-Geneidy and Levinson).

b) The individual-accessibility measures (papers by Román and Martín; Jiménez and Perdiguero; and Sabir et al.)

We hope that this Special Issue (by means of these six contributions) can offer an overview of the recent methodological directions in accessibility, and that the methods, analysis and policy conclusions can be sufficiently provocative to trigger new research in this intriguing and amazing field. There are still many questions that remain open, in particular, how transport networks affect spatial interaction, and how industrial organization, network economics and land use, in general, are highly affected by access times to particular and emblematic nodes of transport and communication networks. In fact, we have still more questions than answers in this

Table 1 Characteristics of the accessibility models included this Special Issue

\begin{tabular}{|c|c|c|c|c|c|}
\hline Authors & Area of study & $\begin{array}{l}\text { Transport } \\
\text { system }\end{array}$ & $\begin{array}{l}\text { Economic } \\
\text { activities }\end{array}$ & People & Measure \\
\hline Östh & $\begin{array}{l}\text { KAK region } \\
\text { Köping, Arboga } \\
\text { and Kungsör } \\
\text { (Sweden) }\end{array}$ & Road & Jobs & $\begin{array}{l}\text { Potential } \\
\text { employees }\end{array}$ & Place \\
\hline $\begin{array}{l}\text { Reggiani } \\
\text { et al. }\end{array}$ & Germany & Road & Jobs & $\begin{array}{l}\text { Home to work } \\
\text { commuters }\end{array}$ & Place \\
\hline $\begin{array}{l}\text { El-Geneidy and } \\
\text { Levinson }\end{array}$ & $\begin{array}{l}\text { Minneapolis-St Paul } \\
\text { metropolitan } \\
\text { area (USA) } \\
\text { Montréal (Canada) }\end{array}$ & Road & $\begin{array}{l}\text { Jobs for } \\
\text { resident } \\
\text { workers and } \\
\text { health } \\
\text { services }\end{array}$ & 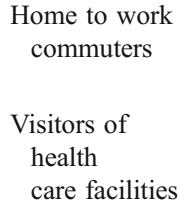 & Place \\
\hline $\begin{array}{l}\text { Román and } \\
\text { Martín }\end{array}$ & $\begin{array}{l}\text { HST Madrid- } \\
\text { Barcelona } \\
\text { Corridor (Spain) }\end{array}$ & Road & $\begin{array}{l}\text { Interurban } \\
\text { trips }\end{array}$ & $\begin{array}{l}\text { HST } \\
\text { interurban } \\
\text { travellers }\end{array}$ & Individual \\
\hline $\begin{array}{r}\text { Jiménez and } \\
\text { Perdiguero }\end{array}$ & Galicia (Spain) & Road & Gas sale & $\begin{array}{l}\text { Gas Service } \\
\text { Stations and } \\
\text { drivers }\end{array}$ & Individual \\
\hline Sabir et al. & Netherlands & Road & Job & $\begin{array}{l}\text { Home to work } \\
\text { commuters }\end{array}$ & Individual \\
\hline
\end{tabular}


topic, so we will wait for the feedback of interesting readers with new models that adjust and complement the characteristics of the models used in this special issue.

All contributions have been refereed. The editors are grateful to all the authors and referees for their valuable and careful collaboration, and also for providing new insights and reflections on the issues mentioned above.

\section{References}

Bruinsma FR, Rietveld P (1998) The accessibility of European cities: theoretical framework and comparison approaches. Environ Plann 30:449-521

Geurs K, van Wee B (2004) Accessibility evaluation of land-use and transport strategies: review and research directions. J Transp Geogr 12(2):127-140

Handy SL, Niemeier DA (1997) Measuring accessibility: an exploration of issues and alternatives. Environ Plann 29 A:1175-1194

Hansen W (1959) How accessibility shape land use. J Am Inst Plann 25(2):73-76

Kwan MP (1998) Space-time and integral measures of accessibility: a comparative analysis using a pointbased framework. Geogr Anal 30:191-216

Miller HJ (2005) Place-based versus people-based accessibility. In: Levinson D, Krizek KJ (eds) Access to destinations. Elsevier, London, pp 63-89

Morris JM, Dumble PL, Wigan MR (1979) Accessibility indicators for transport planning'. Transp Res A 13:91-109

Reggiani A (1998) Accessibility, trade and location behaviour: an introduction. In: Reggiani A (ed) Accessibility, trade and location behaviour. Ashgate, Aldershot, pp 1-16

Vickerman RW (1995) The regional impacts of Trans-European networks. Ann Reg Sci 29:237-254

Weber J, Kwan MP (2003) Evaluating the effects of geographic contexts on individual accessibility: a multilevel approach. Urban Geogr 24:647-671

Weibull JW (1980) On the numerical measurement of accessibility. Environ Plann A 12:53-67 